\title{
Lung sonography
}

Paolo Tomà

From 70th Congress of the Italian Society of Pediatrics, Joint National Meeting SIP, SICUPP, SITIP

Palermo, Italy. 11-14 June 2014

New extensive use of thoracic ultrasound (TUS) takes information also from physical acoustic phenomena that are not directly convertible into images of the human body[1].This tendency also takes into account the classic patterns (based on the presence of an adequate acoustic window) emphasizing the role of TUS as an all-in-one approach in many conditions. We stated our perplexities [2] and we maintain that great caution is warranted when this procedure is used. The evidences on neonatology and paediatrics are based on few articles with different biases i.e.:

No evaluation on technical issues feasibly (the generation of artefacts is conditioned by the time gain compensation setting, the ratio of probe curvature to the curvature of the lung surface, and whether or not movement artefact suppression and tissue harmonics are used), no comparison of the results of TUS and those of a reference standard (i.e. CXR);

Diagnostic access bias (few cases, small hospital), bias from reader/training experience on CXR (no paediatric radiologists);

Imaging analysis bias i.e. absence of preliminary definition of the methods for imaging (CXR) interpretation, selection bias (patients from birth to adult undergoing chest radiography for suspected community acquired pneumonia).

Published: 11 August 2014

\section{References}

1. Volpicelli G, Elbarbary M, Blaivas M, Lichtenstein DA, Mathis $G$,

Kirkpatrick AW, Melniker L, Gargani L, Noble E, Via G, Dean A, Tsung JW, Soldati G, Copetti R, Bouhemad B, Reissig A, Agricola E, Rouby JJ, Arbelot C, Liteplo A, Sargsyan A, Silva F, Hoppmann R, Breitkreutz R, Seibel A, Neri L, Storti E, Petrovic T, International Liaison Committee on Lung Ultrasound (ILC-LUS) for International Consensus Conference on Lung Ultrasound (ICCLUS): International evidence-based recommendations for point-of-care lung ultrasound. Intensive Care Med 2012, 38:577-591.

Correspondence: paolo.toma@opbg.net

Department of Imaging, Bambino Gesù Children's Hospital, IRCCS, Piazza S. Onofrio, 00165 Rome, Italy

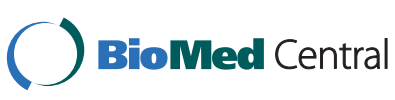

(C) 2014 Tomà licensee BioMed Central Ltd. This is an Open Access article distributed under the terms of the Creative Commons Attribution License (http://creativecommons.org/licenses/by/4.0), which permits unrestricted use, distribution, and reproduction in any medium, provided the original work is properly cited. The Creative Commons Public Domain Dedication waiver (http:// creativecommons.org/publicdomain/zero/1.0/) applies to the data made available in this article, unless otherwise stated.
2. Tomà $\mathrm{P}$, Owens $\mathrm{CM}$ : Chest ultrasound in children: critical appraisal. Pediatr Radiol 2013, 43:1427-1434.

doi:10.1186/1824-7288-40-S1-A7

Cite this article as: Tomà: Lung sonography. Italian Journal of Pediatrics 2014 40(Suppl 1):A7.
Submit your next manuscript to BioMed Central and take full advantage of:

- Convenient online submission

- Thorough peer review

- No space constraints or color figure charges

- Immediate publication on acceptance

- Inclusion in PubMed, CAS, Scopus and Google Scholar

- Research which is freely available for redistribution 